-MRI 所見による検討一

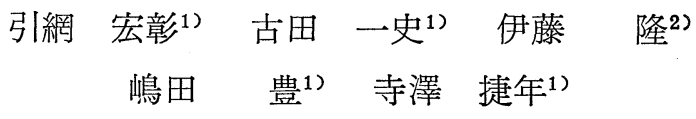

\title{
On the Relationship between Oketsu Syndrome and the Distribution of Multiple Cerebral Infarction on Magnetic Resonance Imaging
}

\author{
Hiroaki HIKIAMI ${ }^{1)}$ Kazufumi KOHTA ${ }^{1)}$ Takashi ITOH $^{2)}$ \\ Yutaka SHIMADA $^{1)}$ Katsutoshi TERASAWA ${ }^{1)}$
}

1) M. D. s, Department of Japanese Oriental (Kampo) Medicine, Faculty of Medicine, Toyama Medical and Pharmaceutical University, Sugitani 2630, Toyama-shi, 930-11, Japan

2) M. D., Department of Internal Medicine, Division of Japanese Oriental Medicine, Toyama Prefectural Central Hospital, Nishinagae 2-2-78, Toyamashi-930, Japan

\begin{abstract}
The authors examined the ralationship between 'Oketsu' syndrome and multiple cerebral infarction. In the 59 patients ( $62.8 \pm 9.5$ years of age; 43 male and 16 female) with multiple cerebral infarction who had undergone MRI examinations, the authors evaluated the 'Oketsu' score, DEA (maximum diameter of the column of intravasclar erythrocyte aggregation) and erythrocyte aggregability.
\end{abstract}

The control group, 18 subjects (61.2 29.3 years of age; 11 male and 7 female) had no findings of cerebral infaction upon MRI examination.

In the patient group, the 'Oketsu' score was higher than the control group $(\mathrm{P}<0.0001)$ and microcirculation was significantly impaired $(\mathrm{P}<0.01)$.

According to localization of foci in the MRI study, the microcircuation was particularly impaired when infarctions occurred in areas controlled by the cortical branches $(\mathrm{P}<0.05)$.

Both symptomatic and asymptomatic infarctions presented high 'Oketsu' scores and impairment of microcirculation.

Erythrocyte aggregability significantly increased in patients in the multiple infarction symptomatic group $(\mathrm{P}<0.05)$. Particulaly, patients suffering from cerebral infarctions in the cortical branches had more severe erythrocyte aggregation.

Key words: Oketsu syndrome, multiple cerebral infarction, MRI, erythrocyte aggregability

Abbreviations: $M R I=$ Magnetic resonance imaging, $D E A=$ Maximum diameter of the column of intravascular erythrocyte aggregation, IEA = Intravoscular eryhrocyte aggregation

1) 医, 富山医科薬科大学医学部和漢診療学, 富山, =930-11 富山市杉谷2630

2) 医, 富山県立中央病院内科 (和漢診療), 富山, 干930 富山市西長江 2-2-78

[1995年 8 月 7 日受理] 
Nihon Toyo Igaku Zasshi (Japanise Journal of Oriental Medicine), 46, 547-554, 1956 (accepted 7 Aug, 1995)

\section{緒 言}

近年 Magnetic resonance imaging (MRI) を はじめとする画像診断の進歩により，脳血管障害 の病巣検出率は飛躍的に向上した。これに伴って 臨床症状を呈さない無症候性脳梗塞患者の診断率 が増加してきたことから，無症候性脳梗塞患者へ の対応が新たな診療上の問題点となってきてい る。

このような中で，多発性脳梗塞患者に执いて東 洋医学的病態概念を導入し，その臨床的背景にど のような違いが認められるかを検討し，東洋医学 的治療が果たせる役割を探ることは重要な意味を 持つと思われる。

我々はこれまでに, 疙血病態に扮いては血液粘 度, 赤血球集合能 (erythrocyte aggregability), フィブリノーゲン值等の血液レオロジーの異常が 又られ ${ }^{12)}$ ， 七下眼球結膜の観察により微小循環 障害が生じることを明らかにした ${ }^{3)}$ 。また特に多 発性脳梗塞患者に沶いては, 瘀血の重症度が進む につれて血液レオロジー異常も増強することを報 告してきた2)。

一方，MRI によって診断される多発性脳梗塞 の病巣分布をその支配動脈の相違に基づいて，成 因や危険因子を分析する研究も進んでいる。すな わち，皮質枝系の梗塞と穿通枝系の梗塞を起こす 患者では, 臨床的背景が異なることが指摘されて

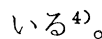

以上の観点から我々は，MRI 上の多発性脳梗 塞の有無, 病巣分布, 症候の有無と疙血病態, 血 液レオロジー上の指標との関連性について 検討 し，新たな知見を得たので報告する。

\section{対象と方法}

1) 対象

1992年 4 月から1994年12月までに富山医科薬科 大学附属病院和漢診療部を受診した患者の中で, 頭部 MRI 検查を施行した患者77例（62.4 49.4
歳，男性54例，女性23例）を対象とした。初診時 の基礎疾患の内訳は，脳梗塞後遺症27例，高血圧 症 11 例, 糖尿病 7 例, 慢性頭痛 6 例, 頸 椎 症 5 例，肝機能障害 4 例，狭心症-慢性胃炎 - 更年期 障害・レイノ一症候群各 3 例，心房細動・便秘・ 顎関節症・舌痛症・アトピー性皮膚炎各 1 例であ った。このうち脳梗塞後遺症以外の症例について は，頭痛やふらつきなどの症候の精査のため，頭 部 MRI 検査が施行された。

2）方法

多発性脳梗塞の診断 : 1.5tesla 高磁場 MRI （Siemens Magneton H15）を使用し，T1強調 像として spin echo 法 $(\mathrm{TR} / \mathrm{TE}=500 / 15), \mathrm{T} 2$ 強調像として spin echo 法 $(\mathrm{TR} / \mathrm{TE}=2500 / 90)$ を用いた。 $\mathrm{T} 1$ 強調像で低信号，T2 強調像で高信 号を示す多発性病巣の所見を有するものを多発性 脳梗塞と診断した。この中から梗塞巣に近似し, 本質的に異なる所見とされる Leuko-araiosis を 除外するために, Braffman $5^{5)}$ や Heier $5^{6)}$ の 提言に基づき，(1)撮像に用いたすべての pulse sequence で髄液と等信号を呈する，(2)直径（長 径) が $4 \mathrm{~mm}$ 以下である，(3)左右対称性比出現し ている，の 3 条件全てを満たす所見を非梗塞性所 見として，検討から除外した。

症例の分類：頭部 MRI 検査で梗塞の所見を全 く認めなかった群を対照群（18例；男性11例，女 性 7 例）とし，多発性脳梗塞と診断した患者59例 （男性43例，女性16例）を梗塞群とした。さらに 大西ら ${ }^{4)}$ の方法に従って梗塞群を MRI 所見によ り以下の 3 群に分類した（図 1)。多発性病巣の 分布が穿通枝系に属する基底核・内包・視床特よ び橋に優勢なものを基底核型（19例；男12例，女 7 例）とし，皮質枝系に属する大脳皮質・皮質下 白質（半卵円中心）拈よび小脳に優勢なものをび まん性白質型（20例；男15例，女 5 例）として, これら双方の所見を有する群を混合型（20例；男 16例，女 4 例）とした。図 2 には基底核型とびま ん性白質型の典型的な MRI の T2 強調像を示し 


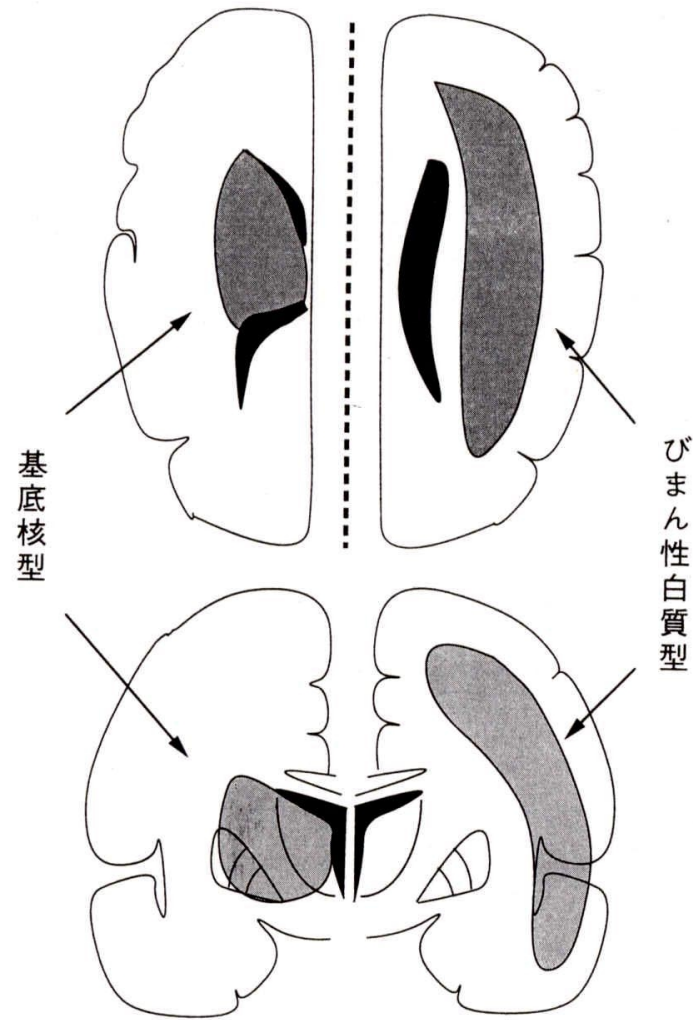

図 1 MRI 所見からみた多発性脳梗塞の 病巣分布の分類

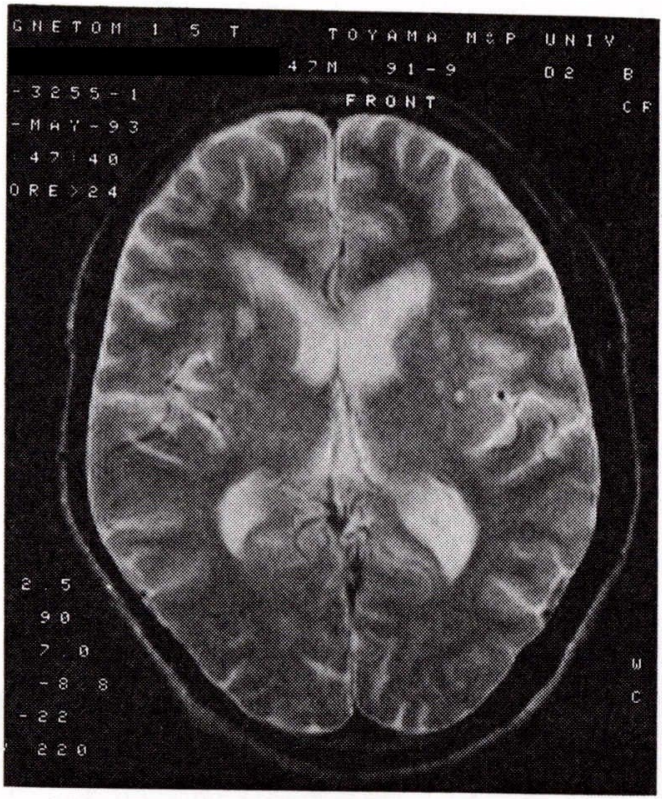

基底核型

た。また，梗塞所見に一致する神経症候を有する 症候性脳梗塞群と，いままでに梗塞に一致した神 経症候の出現を全く認めない無症候性脳梗塞群に 分類した。

疠血スコア：対象患者の瘀血スコアを科学技術 庁瘀血研究班による疙血診断基準 に基ついて算 出した。診断は東洋医学会専門医 5 名によって行 った。

微小循環障害の評価: 生体で観察される微小循 環障害の指標として, 眼球結膜微小循環ビデオ観 察システムを用いて眼球結膜微小血管の血管内赤 血球集合最大円柱径 (DEA ; maximum diameter of the column of intravascular erythrocyte aggregation）を測定した。DEA は，血管内赤血 球集合 (IEA; intrvascular erythrocyte aggregation）がみられる血管の最大径と定義した2)。 血液レオロジー因子の測定 : 领血と関連性を有す る血液レオロジー異常の指標として，赤血球集合 能 (erythrocyte aggregability) を用いた。赤血 球集合能の測定には SEFAM ${ }^{\mathrm{TM}}$ Erythro-aggregometer を用い, High share rate $\left(600 \mathrm{sec}^{-1}\right)$ で血液サンプルを10秒間攪拌し，その後のレーザ

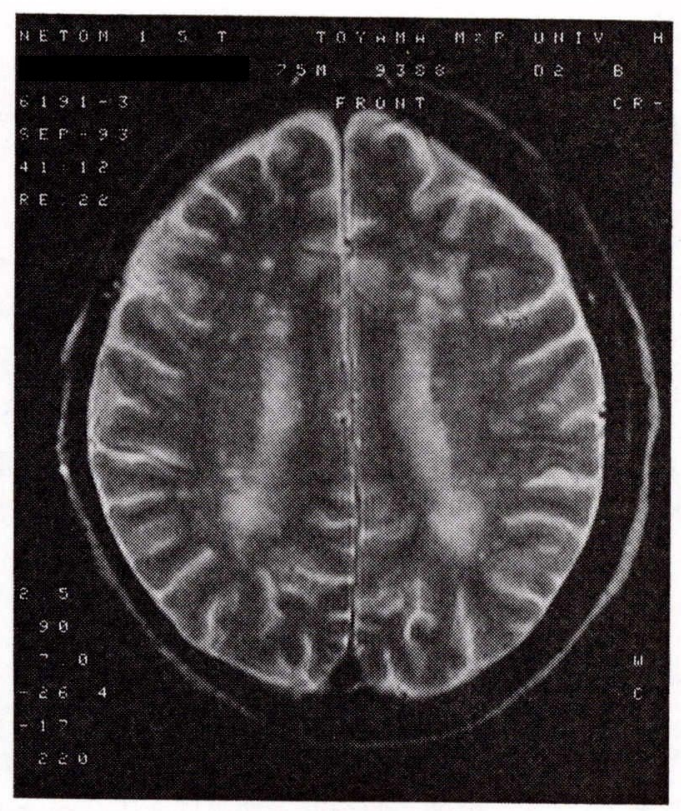

びまん性白質型

図 2 多発性脳塞梗の病巣分布による分類の典型的 MRI 像 
表 1 対照群と梗塞群の背景因子の比較

\begin{tabular}{|c|c|c|c|c|c|c|c|c|}
\hline 群 & 性 & 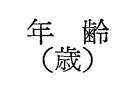 & $\begin{array}{c}\text { 収縮期血压 } \\
\text { (mmHg) }\end{array}$ & $\begin{array}{l}\text { 拡張期血压 } \\
\text { (mmig) }\end{array}$ & $\begin{array}{l}\text { ヘマトクリ } \\
\text { ット } \\
(\%)\end{array}$ & $\begin{array}{l}\text { 総コレステ } \\
\text { 口ール } \\
(\mathrm{mg} / \mathrm{d} \ell)\end{array}$ & $\begin{array}{l}\text { 中性脂肪 } \\
(\mathrm{mg} / \mathrm{d} \ell)\end{array}$ & $\begin{array}{l}\text { 空腹時血糖 } \\
(\mathrm{mg} / \mathrm{d} \ell)\end{array}$ \\
\hline $\begin{array}{c}\text { 対照群 } \\
(\mathrm{n}=18)\end{array}$ & $\begin{array}{l}\text { 男: } 11 \\
\text { 女: } 7\end{array}$ & $\begin{array}{l}61.2 \\
\pm 9.3\end{array}$ & $\begin{array}{l}124.7 \\
\quad \pm 14.5\end{array}$ & $\begin{array}{l}72.0 \\
\pm 8.4\end{array}$ & $\begin{array}{l}43.1 \\
\quad \pm 3.7\end{array}$ & $\begin{aligned} 184 . & 6 \\
& \pm 37.6\end{aligned}$ & $\begin{aligned} \text { 128. } & 6 \\
& \pm 68\end{aligned}$ & $\begin{array}{l}106.5 \\
\quad \pm 17.1\end{array}$ \\
\hline $\begin{array}{c}\text { 梗塞群 } \\
(\mathrm{n}=59)\end{array}$ & $\begin{array}{l}\text { 男: } 43 \\
\text { 女: } 16\end{array}$ & $\begin{array}{l}62.8 \\
\quad \pm 9.5\end{array}$ & $\begin{array}{l}134.5 \\
\quad \pm 17.1\end{array}$ & $\begin{array}{l}79.9 \\
\quad \pm 12.9\end{array}$ & $\begin{array}{l}\text { 43. } 3 \\
\quad \pm 3.7\end{array}$ & $\begin{aligned} 193.3 & \\
& \pm 29.5\end{aligned}$ & $\begin{array}{l}123.0 \\
\pm 64\end{array}$ & $\begin{array}{l}100.3 \\
\quad \pm 16.3\end{array}$ \\
\hline
\end{tabular}

表 2 梗塞病巣分布による subtype の背景因子の比較

\begin{tabular}{|c|c|c|c|c|c|c|c|c|}
\hline 群 & 性 & $\begin{array}{l}\text { 年齢 } \\
\text { (歳) }\end{array}$ & $\begin{array}{c}\text { 収縮期血压 } \\
(\mathrm{mm} H \mathrm{~g})\end{array}$ & $\begin{array}{c}\text { 拡張期血圧 } \\
(\mathrm{mm} \text { ) }\end{array}$ & $\begin{array}{l}\text { ヘマトクリ } \\
\text { ット } \\
\quad(\%)\end{array}$ & $\begin{array}{l}\text { 総コレステ } \\
\text { 口ール } \\
(\mathrm{mg} / \mathrm{d} \ell)\end{array}$ & $\begin{array}{l}\text { 中性脂肪 } \\
(\mathrm{mg} / \mathrm{d} \ell)\end{array}$ & $\begin{array}{l}\text { 空腹時血糖 } \\
(\mathrm{mg} / \mathrm{d} \ell)\end{array}$ \\
\hline $\begin{array}{l}\text { 基底核型 } \\
(\mathrm{n}=19)\end{array}$ & $\begin{array}{l}\text { 男: } 12 \\
\text { 女: } 7\end{array}$ & $\begin{aligned} 58 . & 8 \\
& \pm 9.5\end{aligned}$ & $\begin{array}{l}130.0 \\
\quad \pm 16.4\end{array}$ & $\begin{array}{l}74.7 \\
\quad \pm 10.6\end{array}$ & $\begin{array}{l}41.8 \\
\pm 2.6\end{array}$ & $\begin{array}{l}197.3 \\
\quad \pm 22.1\end{array}$ & $\begin{aligned} 113 . & 5 \\
& \pm 59\end{aligned}$ & $\begin{array}{l}96.5 \\
\quad \pm 14.8\end{array}$ \\
\hline $\begin{array}{l}\text { びまん性 } \\
\text { 白質型 } \\
(n=20)\end{array}$ & $\begin{array}{l}\text { 男: } 15 \\
\text { 女: } 5\end{array}$ & $\begin{array}{l}65.3 \\
\quad \pm 8.5\end{array}$ & $\begin{array}{r}137.4 \\
\quad \pm 16.7\end{array}$ & $\begin{array}{l}81.8 \\
\quad \pm 13.5\end{array}$ & $\begin{array}{l}44.3 \\
\quad \pm 4.5\end{array}$ & $\begin{array}{l}197.0 \\
\pm 35.2\end{array}$ & $\begin{array}{r}122.9 \\
\pm 67\end{array}$ & $\stackrel{97.1}{ \pm 13.1}$ \\
\hline $\begin{array}{l}\text { 混合型 } \\
(\mathrm{n}=20)\end{array}$ & $\begin{array}{l}\text { 男: } 16 \\
\text { 女: } 4\end{array}$ & $\begin{array}{l}64.0 \\
\quad \pm 9.6\end{array}$ & $\begin{array}{l}133.9 \\
\quad \pm 18.5\end{array}$ & $\begin{array}{l}80.9 \\
\quad \pm 13.3\end{array}$ & $\begin{array}{l}\text { 43. } 9 \\
\quad \pm 3.5\end{array}$ & $\begin{array}{l}186.6 \\
\quad \pm 29.0\end{array}$ & $\begin{aligned} 130.7 & \\
& \pm 68\end{aligned}$ & $\begin{array}{l}105.8 \\
\quad \pm 18.7\end{array}$ \\
\hline
\end{tabular}

一光が散乱する強度から得られたS 10を指標とし て用いた2。

血液レオロジーに影響を与える因子である年 齢，血圧，へマトクリット，血中脂質成分，血糖 值も群間で比較した。な和高血圧，高脂血症，糖 尿病については，すでに治療され良好なコントロ ールが得られていた。

\section{3) 統計学的解析方法}

結果は mean $\pm \mathrm{SD}$ で示した。独立性の検定に は $\chi^{2}$ 検定を用い，独立 2 群の有意差検定に $\mathrm{t}$ 検 定を用いた。独立多群の有意差検定にはANOVA 検定を用いて，有意差がある場合に Post-Hoc test として, Fisher's PLSD 法を用い各群間の差 を検定した。全ての検定に拈いて危険率 $5 \%$ 未満 をもって有意差ありと判定した。

\section{結 果}

1）背景因子の検討

対照群と梗塞群の患者の背景因子を比較した （表 1 ）。性，年齢，収縮期・拡張期血圧，へマト クリット, 総コレステロール, 中性脂肪, 空腹時
表 3 対照群と梗塞群の比較

\begin{tabular}{cccc}
\hline & & $\begin{array}{c}\text { 対照群 } \\
(\mathrm{n}=18)\end{array}$ & $\begin{array}{c}\text { 梗塞群 } \\
(\mathrm{n}=59)\end{array}$ \\
\hline 瘀血スコア & $($ 点 $)$ & $12.9 \pm 6.4$ & $32.9 \pm 13.1^{\S}$ \\
$\mathrm{DEA}$ & $(\mu \mathrm{m})$ & $21.3 \pm 5.5$ & $30.6 \pm 9.5^{* *}$ \\
赤血球集合能 & & $24.2 \pm 3.0$ & $24.8 \pm 3.8$ \\
\hline
\end{tabular}

$$
\S \mathrm{p}<0.0001 * * \mathrm{p}<0.01 \quad(\text { mean } \pm \mathrm{SD})
$$

血糖に扣いては，2 群間で有意差を認めなかっ た。

また同様に梗塞群に抏いて梗塞病巣分布から分 類した subtype 即ち基底核型（19例）びまん性 白質型 (20例), 混合型 (20例) についても，背 景因子の比較を行ったが，これらの間にも有意な 相違は認められなかった（表 2 ）。

\section{2）対照群と梗塞群の検討（表 3)}

瘀血スコアは対照群は $12.9 \pm 6.4$ 点であったの に対して, 梗塞群は32.9土13.1点と有意に高い值 を示した（P<0.0001）。DEA は対照群で21.3土 $5.5 \mu \mathrm{m}$ であったが，梗塞群では $30.6 \pm 9.5 \mu \mathrm{m}$ と これも有意に高い値を示した $(\mathrm{P}<0.01)$ 。赤血球 
表 4 多発性脳梗塞の病巣分布による比較

\begin{tabular}{|c|c|c|c|c|c|}
\hline & \multirow{2}{*}{$\begin{array}{c}\text { 対照群 } \\
(n=18)\end{array}$} & \multicolumn{3}{|c|}{ 梗塞群 } & \\
\hline & & $\begin{array}{l}\text { 基底核型 } \\
(\mathrm{n}=19)\end{array}$ & $\begin{array}{c}\text { びまん性白質型 } \\
(\mathrm{n}=20)\end{array}$ & $\left(\begin{array}{c}\text { 混合型 } \\
\mathrm{n}=20\end{array}\right)$ & \\
\hline 瘀血スコア(点) & $12.9 \pm 6.4$ & $31.6 \pm 15.2^{8}$ & $33.7 \pm 13.58$ & $33.4 \pm 10.8^{8}$ & $\mathrm{p}<0.0001^{\mathrm{a}}$ \\
\hline $\operatorname{DEA}(\mu \mathrm{m})$ & $21.3 \pm 5.5$ & $26.1 \pm 9.2$ & $31.1 \pm 9.1^{*}$ & $33.1 \pm 9.5^{* * *}$ & $\mathrm{p}<0.01^{\mathrm{a}}$ \\
\hline 赤血球集合能 & $24.2 \pm 3.0$ & $23.3 \pm 3.2$ & $26.1 \pm 4.4$ & $24.8 \pm 3.3$ & N. S. a \\
\hline
\end{tabular}

a : ANOVA検定

$($ mean $\pm \mathrm{SD})$

b : Fisher's PLSD 法 $\S \mathrm{p}<0.0001 \quad * * * \mathrm{p}<0.001 * \mathrm{p}<0.05$

表 5 無症候性脳梗塞群と症候性脳梗塞群の比較

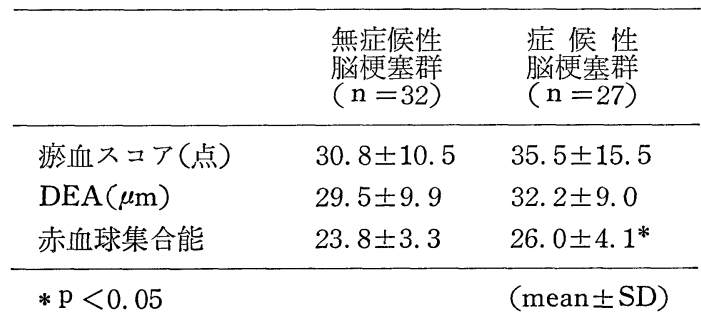

集合能は 2 群間で有意差は認めなかった。

3 ) 多発性脳梗塞の病巣分布による検討(表 4) 瘀血スコアは対照群・基底核型・びまん性白質 型・混合型の 4 群間に执いて ANOVA 検定では 有意差がみられ $(\mathrm{P}<0.0001)$ ，更に Fisher's PLSD 法で 2 群間の比較を行ったところ, 対照群 に比し基底核型 $31.6 \pm 15.2$ 点，びまん性白質型 $33.7 \pm 13.5$ 点, 混合型 $33.4 \pm 10.8$ 点といずれも有 意に高い值を示した $(\mathrm{P}<0.0001)$ 。DEA も 4 群 間で有意差がみられ $(\mathrm{P}<0.01)$, 対照群に比し基 底核型では26.1 $\pm 9.2 \mu \mathrm{m}$ で有意差はなかったが， びまん性白質型では $31.1 \pm 9.1 \mu \mathrm{m}(\mathrm{P}<0.05)$, 混合型では33.1 $\pm 9.5 \mu \mathrm{m}(\mathrm{P}<0.001)$ とこの両者 で有意に高值を示した。赤血球集合能に関しては 各群間の差は明らかではなかった。

4) 症候性脳梗塞と無症候性脳梗塞との比較

\section{(表 5)}

梗塞群の中で頭部 MRI 検査で認められた梗塞 所見に一致する神経症候を有する群（症候性脳梗 塞群 27 例， $63.0 \pm 8.5$ 歳，男 18 :女 9 ）といまま で梗塞に一致した神経症候の出現を全く認めない 患者群（無症候性脳梗塞群32例，62.6 6 10.4歳， 男25：女 7) による比較を行った。尚この 2 群
間にも性，年齢，血圧，血液生化学的データに有 意性は認めなかった。無症候性脳梗塞群と症候性 脳梗塞群の 2 群間に扣いて，瘀血スコアと DEA には有意差は認められなかった。しかし赤血球集 合能は無症候性脳梗塞群が $23.8 \pm 3.3$ であるのに 対して, 症候性脳梗塞群では $26.0 \pm 4.1$ と有意な 充進がみられた $(\mathrm{P}<0.05) 。$

MRI 所見の病巣分布によって分類した subtype に颃いても症候の有無について検討した （図 $3 ・ 4$ ）。基底核型及び混合型においては，瘀 血スコア・DEA・赤血球集合能のいずれにおい ても無症候性脳梗塞群と症候性脳梗塞群の間に有 意な差は認められなかった。一方びまん性白質型 では疠血スコア・DEA では有意差は検出されな いものの症候性脳梗塞群に拈いて高い值を示す傾 向がみられ，赤血球集合能では無症候性脳梗塞群 が 23.3土4.4 であるのに対して, 症候性脳梗塞群 では $29.6 \pm 2.9$ と高く, 赤血球集合能の有意な克 進が認められた $(\mathrm{P}<0.001) 。$

\section{考 察}

脳血管障害は，現在では悪性新生物扝よび虚血 性心疾患に次ぎ，日本人の死因の第三位にまで減 少した。これは高血圧, 糖尿病なぞの危険因子に 対する管理の成果といえる。乙かし死亡率は減少 したものの発症率はむしろ増加傾向にあることが 最近の報告8) 10) で指摘されている。その理由と しては, 最近の画像診断の進歩により，いわゆる 無症候性脳梗塞といった軽症の脳血管障害が発見 されるようになったことと，高齢化によって65歳

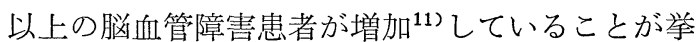



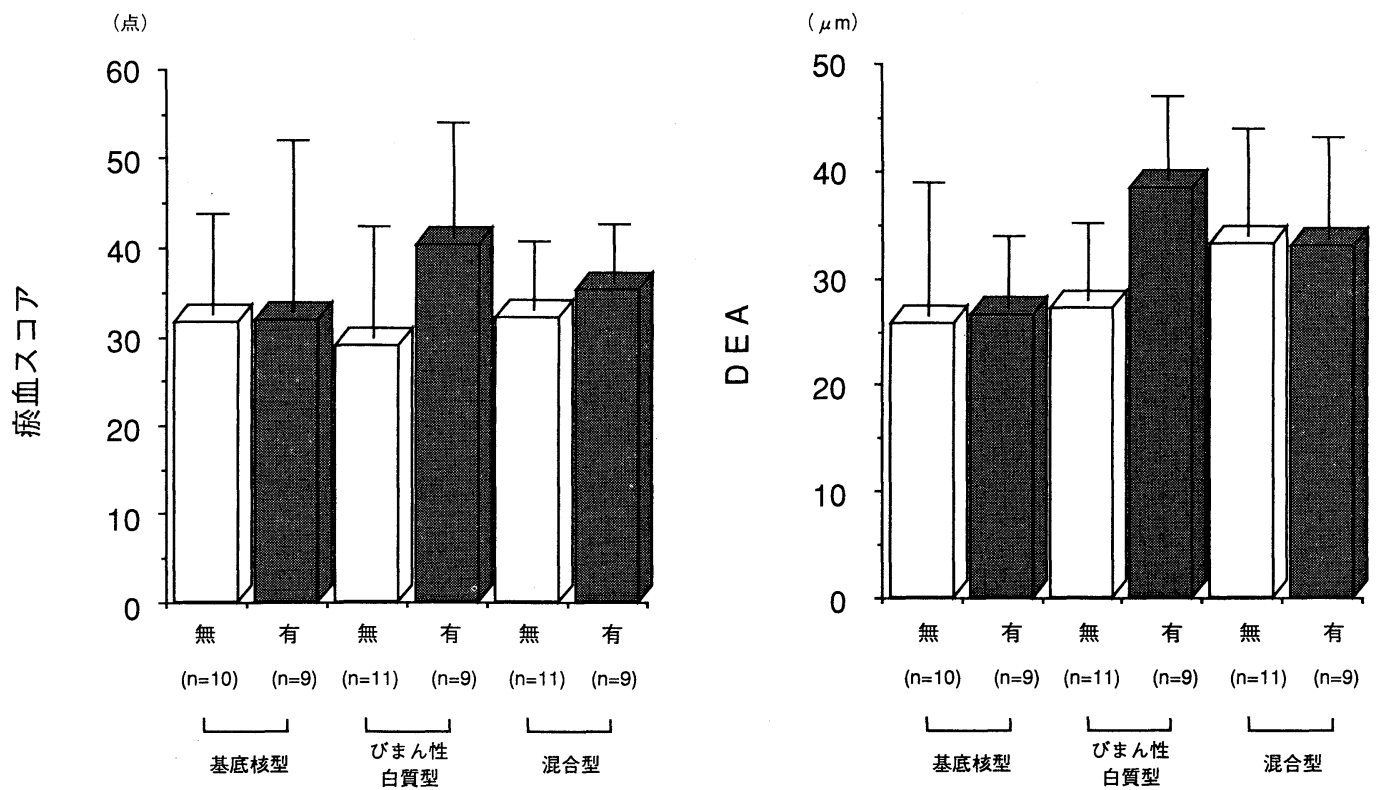

図 3 梗塞の既往からみた疙血スコア・DEA の subtype の間の比較

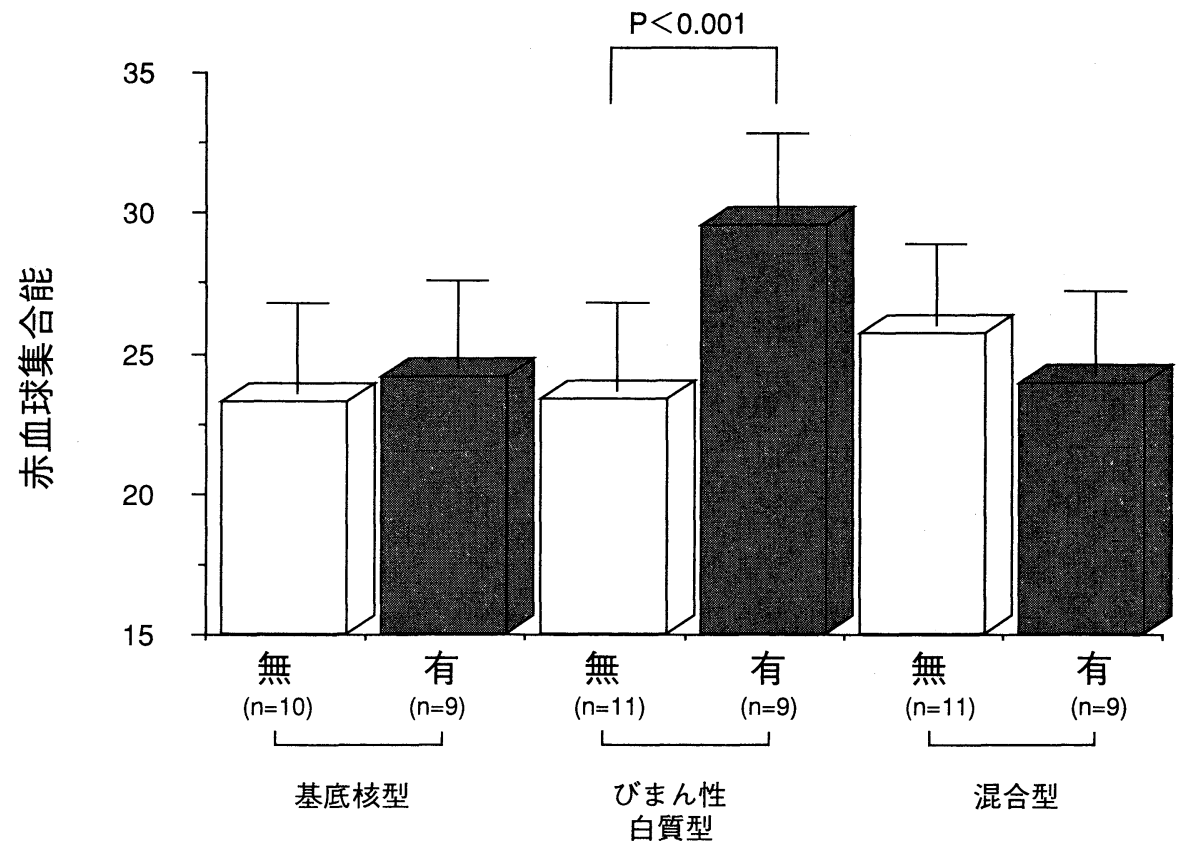

図 4 梗塞の既往からみた赤血球集合能の subtype の間の比較

げられる。また無症候性脳梗塞が症候性脳梗塞や 脳血管性痴呆の発症と深く関わっていることも報
告されている1213)。さらに注目すべきこととして は, National Instiute of Neurological Disor- 
ders and Stroke (NINDS) の特別委員会報告と して出された “脳血管障害の分類 III 班 (CVDIII)” ${ }^{14)}$ によると，脳卒中の危険因子の一つとして MRI, CT による silent infarction and hemorrhage が挙げられている。これらのことから画 像診断の進歩によって診断しうるようになった無 症候性脳梗塞に対する臨床上の対応が，21世紀の 超高齢化社会を目前として軽視できない問題とな ってきている。

今回我々の行った検討は, $50 ７ 0$ 代の中高齢者 に限ったものであるが，MRI で多発性脳梗塞の 所見のある者に疼血病態が強く認められる傾向が あることが示された。领血とは柴崎の定義 ${ }^{15} に よ$ れば「スラスラと流通すべき血液が，何らかの原 因でつかえて，スムースに流れなくなった状態 (病状)」とされ, 矢数 ${ }^{16)}$ は领血によって起こり易 い疾患の一つとして, 動脈硬化症や脳軟化症を挙 ゲている。このように瘀血とは，もともと血栓症 や脳血管障害と関連した病態であることが想定さ れていたが，今回の我々の検討はこのことを実証 したものと考えられる。

さらに亀山ら ${ }^{17)}$ は, 脳動脈の支配によって梗塞 の成立に関わる危険因子が異なることを指摘し た。すなわち皮質枝系梗塞では粥状動脈硬化が, 穿通枝系では細動脈硬化が背景として関わるとい われている1。今回の検討で用いた MRI 所見上 の分類のらち，基底核型は穿通枝系梗塞，びまん 性白質型は皮質枝系梗塞でみられる MRI 上の所 見であり，混合型には当然皮質枝系梗塞の所見も 含まれている。これらの中でびまん性白質型と混 合型では, 瘀血に伴ってみられる微小循環障害が 強く認められた。この結果は领血が粥状動脈硬化 と強く関わっている可能性を示唆している。

今回我々が調査した多発性脳梗塞患者59例のう ち，32例は梗塞や一過性脳虚血発作などの既往が 無く, 梗塞巣に一致した神経学的異常を有しなか った。従ってこれらは無症候性脳梗塞に相当する 病態であると考觉られる。

その中で疠血で認められる血液レオロジー異常 をMRI 所見による梗塞の病巣分布でみると,び まん性白質型では無症候性脳梗塞群に対して, 症
候性脳梗塞群に有意な赤血球集合能の立進がみら れた。

Coull ら ${ }^{18}$ は血液の粘稠度の上昇が脳梗塞の急 性期のみならず，一過性脳虚血発作を来した患者 や高血压・糖尿病・契煙などの脳梗塞の危険因子 を有する者にもすでに認められていることを示 し, 慢性的な血液の高粘稠状態が脳梗塞発症の危 険因子であると述べている。すた Shinohara ら ${ }^{199}$ は脳梗塞患者に执いて赤血球集合能が有意に立 進していると述べている。またこれまでに我々は 领血の重症度と赤血球集合能には正の相関関係が みられることを示した ${ }^{3)}$ 。これらのことから血液 レオロジー異常が脳梗塞の発症との密接な関係が 示唆されるが, 瘀血状態が血液レオロジー異常と 強く関連していることから, 瘀血が脳梗塞の発症 に何らかの影響を与えている可能性がある。

今回我々は血液粘度を規定する因子であるへマ トクリットや血漿脂質成分や血糖について，す心゙ て正常化した患者を対象として赤血球集合能の測 定を行った。そのうえでびまん性白質型の症候性 脳梗塞群で赤血球集合能が有意に充進していたこ とは, 瘀血病態にみられる血液レオロジー異常 が，脳梗塞の発症およびその重症化に関わってい る可能性があることを示している。

東洋医学には“未病を治す”といら独特の治療 理念があるが，現代の先進的画像診断より生じた 無症候性脳梗塞という新たな病態に，领血という 伝統医学的な病理概念を導入し, 駆瘀血剤によっ て症候性脳梗塞への伸展を未然に防ぐことが可能 であるか，今後検討していく必要があると思われ る。

\section{総 括}

多発性脳梗塞の MRI 所見と瘀血との関連性に ついて検討した。MRI で梗塞の所見があるもの は，所見のないものに比べ疼血病態が有意に高度 であり，同時に微小循環障害も強く認められた。 特に皮質枝系脳梗塞ではこの傾向が強かった。ま た症候性脳梗塞と無症候性脳梗塞を比較した場 合，症候を有する場合に瘀血病態が明らかであ り, 微小循環障害が高度で, 血液レオロジーの異 
常も認められた。

本稿の要旨は, 第 45 回日本東洋医学会学術 総会 (1994，神戸）飞执いて発表した。

\section{文 献}

1) Terasawa, K., et al: Rheological studies on "oketsu" syndrome I. The blood viscosity and diagnostic criteria. J. Med. Pharm. WAKAN. YAKU, 3, 98-104, 1986

2) Kohta, K., et al: Hemorheological studies of "oketsu" syndrome -Eeythrocyte aggregation in "oketsu" syndrome-. J. Med. Pharm. WAKAN-YAKU, 9, 221-228, 1992

3 ) Terasawa, K., et al: The characteristics of the microcirculation of bulbar conjunctiva in "oketsu" syndrome. J. Med. Pharm. WAKANYAKU, 5, 200-205, 1988

4) 大西次郎, 他: 無症候性多発性脳梗塞の病巣分布 子臨床的背景一 MRI による検討一, 臨床神経, 31, 610-615, 1991

5) Branffman, B. H., et al: Brain MR: Pathologic correlatioo with gross and histopathology. 2. Hyperintense white-matter foci in the elderly. Am. J. Roentgenol, 151, 559-566, 1988

6) Heier, L. A., et al: Large Virchow-Robin sepaces: MR-clinical correlation. Am. J. Neuroradiol, 10, 929-936, 1989

7）寺澤捷年, 他 : 领血証の症候解析之診断基準の提 唱, 日本東洋医学会誌, 34, 1-17, 1983

8 ）新川，淳, 他：脳卒中発症の明らかでない脳梗塞 一久山町連続剖検例飞よる検討一, 第31回日本老
年医学会総会, 1989

9) Kase C. S., et al: Prevalence of silent stroke in patients presenting with initial stroke-the Framingham study-. Stroke, 20, 850-852, 1989

10）岡田 靖, 他: 画像診断の進歩之無症候性脳血管 障害病変一自験脳梗塞例飞和䄈る年度別検討一, 脳卒中， 12，415-420，1990

11) Broderick J. P., et al: Incidence Rates of Stroke in the Eighties: The End of the De. cline in Stroke? Stroke, 20, 577-582, 1989

12）中川俊男, 他 : 無症候性脳梗塞の症候性への進 行, 綜合臨牀，43，2760-2766, 1994

13）吉武毅人, 他：一般住民飞和汀る脳血管性痴呆発 症率の検討: 久山町研究, 第19回日本 脳卒中学 会, 1994

14) Whistant, J. P., et al: National Institute of Neurological Disorders and Stroke Ad Hoc Committee: Classification of Cerebrovascular Disease III. Stroke, 21, 637-676, 1990

15）柴崎保三：漢方の臨床，16，447-454，1969

16）矢数道明：疼血をめぐって, 日本東洋医学会誌, 25, 165-185, 1975

17）亀山正邦：皮質枝系と穿通枝系一脳梗塞の部位の リスク要因一(会), 脳卒中，1，199-202，1979

18) Coull, B. M., et al: Chronic Blood Hyperviscosity in Subjects With Acute Stroke, Transient Ischemic Attack, and Risk Factors for Stroke. Stroke, 22, 162-168, 1991

19) Shinohara, Y., et al: Hyperaggregability of red blood cells in patients with oclusive cerebrovascular disease. Elsevier Science Publishers BV, 187-190, 1985

要旨 多発性脳梗塞と瘀血との関連性について検討した。MRI で多発性脳梗塞を指摘され

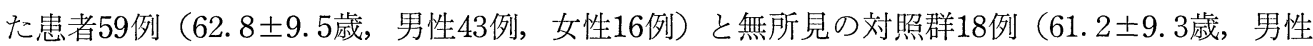
11例，女性 7 例）について瘀血スコア，DEA，赤血球集合能を測定した。多発性脳梗塞患者 では対照群に比し疠血スコアが高く $(\mathrm{P}<0.0001)$, 微小循環障害も認められた $(\mathrm{P}<0.01)$ 。 脳梗塞巣の分布からみると皮質枝の支配する領域の梗塞で, 特に微小循環障害が強かった（P <0.05)。症候性脳梗塞と無症候性脳梗塞について検討したところ，両者で疼血・微小循環障 害が認められたが，赤血球集合能は症候性脳梗塞に打いて有意に充進していた（ $\mathrm{P}<0.05 ）$ 。 特に皮質枝系脳梗塞に㧤いてこの傾向が強く認められた。 